\title{
Hydrologic Conditions in Kansas, Water Year 2017
}

The U.S. Geological Survey (USGS), in cooperation with Federal, State, and local agencies, maintains a long-term network of hydrologic monitoring stations in Kansas. In water year (WY) 2017, the network included 214 real-time streamgages (hereafter referred to as "gages") and 12 real-time reservoir-level monitoring stations. Realtime data are calibrated and validated by USGS personnel throughout the year with regular measurements of streamflow and lake levels. These data and associated analyses provide a unique overview of the hydrologic conditions and help improve the understanding of Kansas' water resources. Yearly assessments of hydrologic conditions are made by comparing statistical analysis of current and past WY data for the period of record. A WY is the 12-month period from October 1 through September 30 and is designated by the calendar year in which it ends. Long-term monitoring of hydrologic conditions in Kansas provides crucial information for protecting of human life and property, managing water supplies, forecasting floods, operating reservoirs, designing bridges and culverts, processing interstate and intrastate water rights claims, ecological monitoring, and many other uses.

\section{Preceding Conditions and Precipitation}

Climate normals are three-decade averages of climatological variables, including precipitation (National Oceanic and Atmospheric Administration, 2018). The National Oceanic and Atmospheric Administration produces a climate normals product every 10 years; the current dataset includes data from 1981 to 2010 (National Oceanic and Atmospheric Administration, 2018). Most of Kansas received greater than normal precipitation in WY 2016. During WY 2017, the western part, part of the north-central area, and most of the eastern border of Kansas received normal to above normal precipitation, whereas the central and northeastern parts of the State received slightly below normal precipitation (National Oceanic and Atmospheric Administration, 2017). The percentage of normal precipitation Kansas received in WYs 2016 and 2017 are compared in figure 1. At the beginning of WY 2017, a little more than 13 percent of the State, mostly in southwestern Kansas, was classified as the drought condition "abnormally dry" (fig. 2; National Drought Mitigation Center, 2017). By the end of
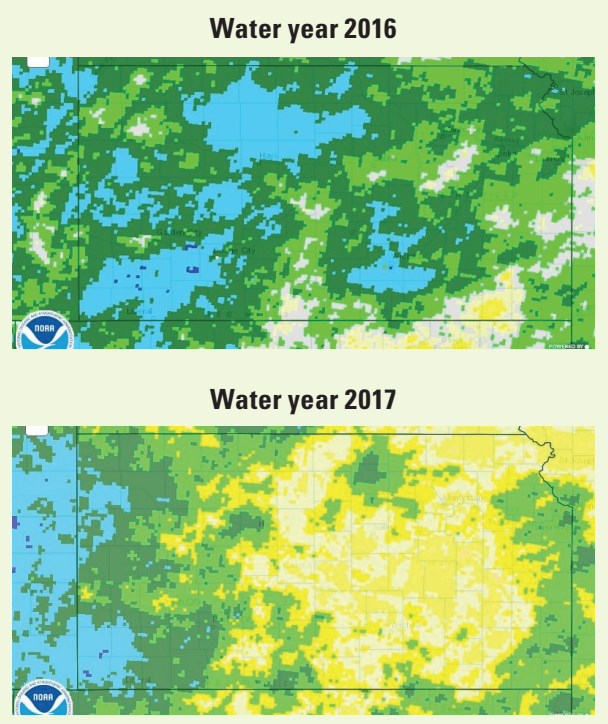

\section{EXPLANATION}

Normal precipitation, in percent

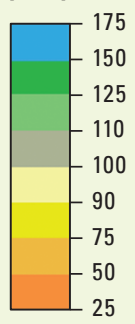

Figure 1. Percentage of normal (19812010) precipitation in Kansas for water years 2016 and 2017 (National Oceanic and Atmospheric Administration, 2017). the WY about 30 percent was classified as abnormally dry, about 9 percent was classified as moderate drought, and about 1 percent of the State was classified as severe drought (National Drought Mitigation Center, 2017). The central and northeastern parts of Kansas were the areas of the State that were affected by drought conditions at the end of the WY (fig. 2; National Drought Mitigation Center, 2017). These areas coincide with the parts of the State that received slightly below normal precipitation during WY 2017. The total area affected by drought in Kansas at the end of WY 2017 was substantially more than at the end of the previous 2 WYs; however, figure 3 shows that WY 2017 had a smaller percentage and far less extreme drought conditions than the end of WYs 2011-14 (National Drought Mitigation Center, 2017).
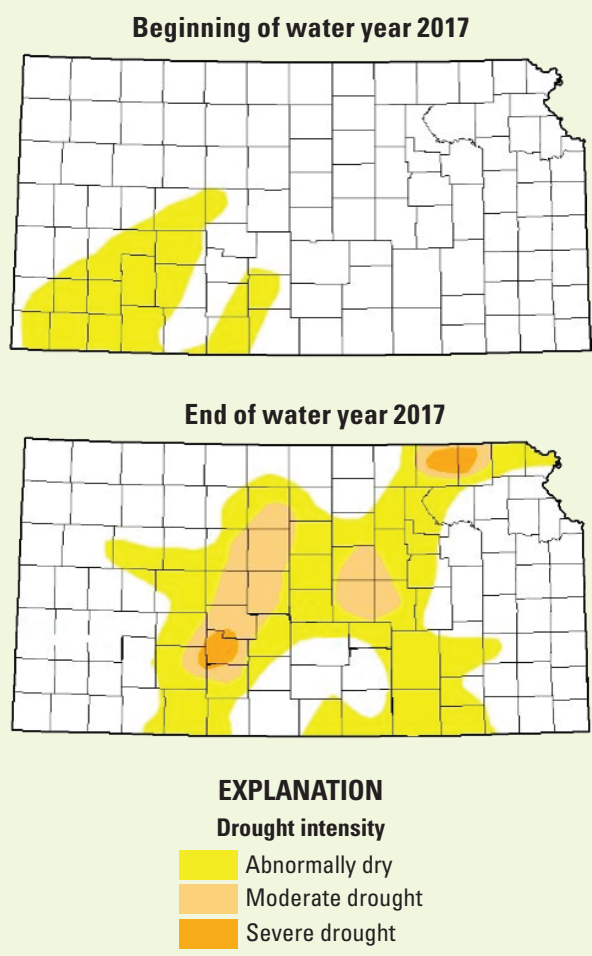

Figure 2. Drought conditions in Kansas at the beginning and end of water year 2017 (National Drought Mitigation Center, 2017). 


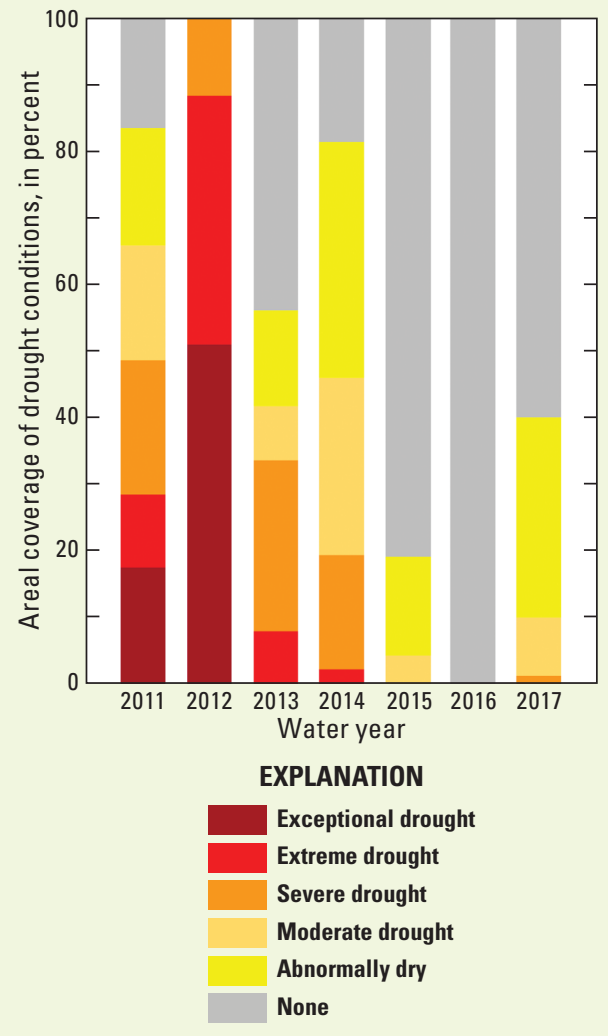

Figure 3. Percent areal coverage of drought conditions in Kansas at the end of water years 2011-17 (National Drought Mitigation Center, 2017).

\section{Streamflow Conditions and Drainage Basin Runoff}

The streamflow conditions in Kansas were normal (25th-75th percentile) throughout most of WY 2017 (fig. 4; U.S. Geological Survey, 2017a). Above normal (76th-90th percentile) and much above normal (greater than 90th percentile) streamflow conditions were present in the eastern one-half and northwestern corner of the State, whereas the drought conditions (fig. 2) contributed to below normal (10th-24th percentile) and record low streamflow conditions in the southwestern part of Kansas at the beginning of the WY. These conditions remained relatively unchanged until April when extensive precipitation throughout Kansas caused the streamflow conditions to increase in range from normal to record high, except for the extreme northwest corner of the State where below normal conditions were present. By July most of the State had normal streamflow conditions. A few areas on the eastern and southern border of Kansas were elevated to above normal conditions because of localized high intensity
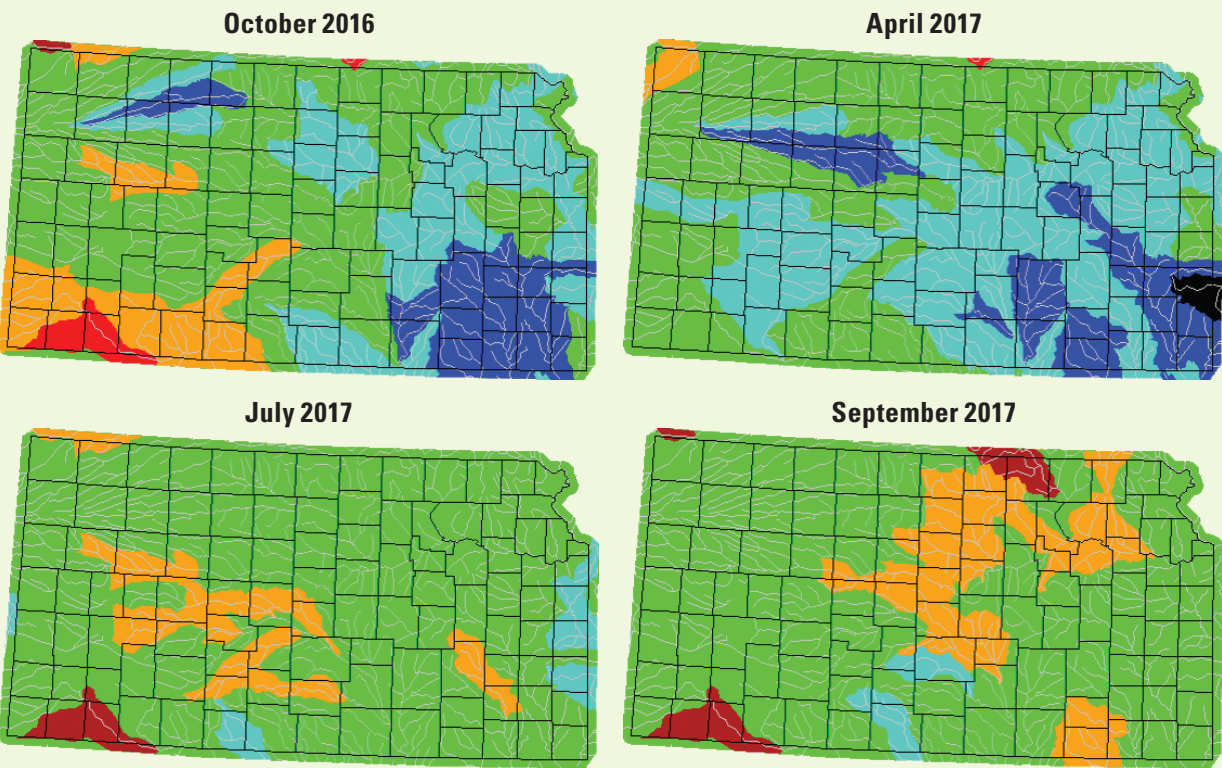

EXPLANATION

\begin{tabular}{|c|c|c|c|c|c|c|c|}
\hline \multirow{3}{*}{ Low } & $<10$ & $10-24$ & $25-77$ & 76 90 & (1) & \multirow{3}{*}{ High } & \multirow{3}{*}{ No data } \\
\hline & Much below & Below & $8 \pi-10$ & Above & Much above & & \\
\hline & normal & normal & Normal & normal & normal & & \\
\hline
\end{tabular}

Percentile classes

Figure 4. Monthly streamflow conditions across Kansas throughout water year 2017 (U.S. Geological Survey, 2017a).

precipitation. Streamflow conditions in central Kansas decreased to below normal conditions, whereas the southwest corner decreased further to much below normal (less than 10th percentile). The WY ended with most of the State having normal streamflow conditions. Parts of central, northeastern, and southeastern Kansas had below normal streamflow, whereas parts of southwestern and northcentral Kansas had much below normal streamflow conditions. These locations coincide with the areas of below normal precipitation and drought conditions at the end of the WY (figs. 1, 2).

Runoff, or streamflow per unit area, is a good indicator of precipitation and streamflow for a drainage basin. Runoff is not solely affected by precipitation contributions for a given area because of groundwater aquifer recharge and reservoir storage, which can prevent water from exiting the basin, decreasing streamflow (Langbein and Iseri, 1960). Quarterly runoff percentiles for WY 2017 are shown in figure 5. Normal to above normal runoff conditions predominated throughout most of the WY. Runoff fell into the 68th percentile of computed runoff and ranked 37th for the State (calculated since 1901, U.S. Geological Survey, 2017a). Parts of western and central Kansas had below normal to much below normal runoff during the first two quarters. Intense precipitation in the third quarter caused much of the State to have above normal runoff conditions. The southeastern corner of Kansas had much above normal runoff conditions, whereas the northwestern and southwestern parts of Kansas still suffered from below normal runoff. Less precipitation and heightened storage in reservoirs caused much of northern and central Kansas to have below normal and much below normal runoff in the last quarter of the WY. A few isolated extreme precipitation events in the fourth quarter caused the eastern border of Kansas to be at above normal or much above normal runoff at the end of the WY (figs. 1, 5).

\section{Reservoirs}

Many of the Federal reservoirs in Kansas were at above normal levels at the beginning of WY 2017 (table 1). All the USGS monitored reservoirs in Kansas exceeded their conservation pool elevations during the year because of heavy precipitation from April through June (National Oceanic and Atmospheric Administration, 2017) except for Cedar Bluff Reservoir near Ellis, Kansas. The resulting high water-surface elevations 

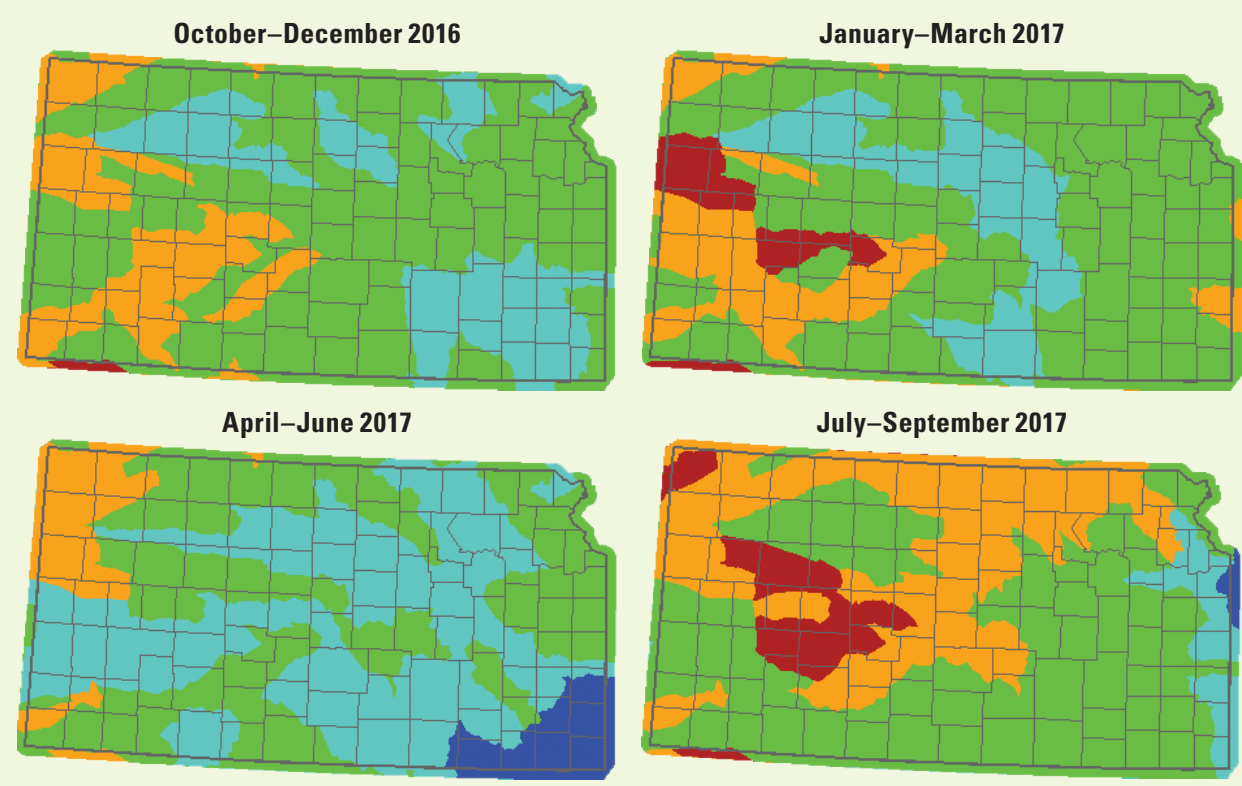

EXPLANATION

\begin{tabular}{|c|c|c|c|c|c|c|c|}
\hline & & & & & & \multirow[b]{3}{*}{ High } & \\
\hline \multirow[b]{2}{*}{ Low } & $<10$ & $10-24$ & $25-75$ & $76-90$ & $>90$ & & \multirow[b]{2}{*}{ No data } \\
\hline & $\begin{array}{c}\text { Much below } \\
\text { normal }\end{array}$ & $\begin{array}{l}\text { Below } \\
\text { normal }\end{array}$ & Normal & $\begin{array}{l}\text { Above } \\
\text { normal }\end{array}$ & $\begin{array}{c}\text { Much above } \\
\text { normal }\end{array}$ & & \\
\hline
\end{tabular}

Percentile classes

Figure 5. Quarterly runoff conditions across Kansas throughout water year 2017 (U.S. Geological Survey, 2017a).

caused many Kansas reservoirs to release higher outflows in April, May, and June; these reservoirs continued steady outflows during the other summer months to reach their respective target conservation pool elevations (U.S. Geological Survey, 2017b). A good example of this is Melvern Lake near Melvern,
Kans. (station 06910997; figs. 6, 7), and the gage below the lake outflow, the Marais des Cygnes River at Melvern, Kans. (station 06911000; figs. 6, 7). The releases from the Kansas reservoirs helped keep streamflow normal in areas of the State that received less than normal precipitation during WY 2017 (figs. 1, 4).
Eleven of the USGS-monitored reservoirs ended the WY with less water than at the beginning of the WY, whereas only Hillsdale Lake near Hillsdale, Kans. (station 06914995; fig. 7), ended the WY with slightly more water.

\section{Streamflow at Selected Streamgages}

Four gages were selected to characterize streamflow conditions in Kansas for WY 2017. Locations of the selected gages are illustrative of the spatial and temporal variability of conditions existing in different regions of the State. The locations of these gages, three other gages discussed in other sections, and USGS lake-level monitoring stations are provided in figure 7.

Stranger Creek near Tonganoxie, Kans. (station 06892000), represents eastern Kansas. Stranger Creek originates in northeast Kansas and flows south into the Kansas River near Linwood, Kans., and has a drainage area of 406 square miles (U.S. Geological Survey, 2017b). Seven-day average flow was above normal at the beginning of the WY (fig. 8). The 7-day average flow dropped briefly to below normal by March. Spring and summer precipitation kept the 7-day average streamflow ranging from normal to much above normal conditions during the second one-half of the WY. This gage closed out WY 2017 with normal

Table 1. Change in water storage during water year 2017 in 12 Federal reservoirs with complete records monitored by the U.S. Geological Survey.

[USGS, U.S. Geological Survey; WY, water year. A water year is a 12-month period from October 1 through September 30 and is designated by the calendar year in which the period ends. Values in red are losses; values in green are gains]

\begin{tabular}{|llcccc}
\hline $\begin{array}{c}\text { USGS } \\
\text { streamgage } \\
\text { number (fig. 7) }\end{array}$ & \multicolumn{1}{c}{ Reservoir name } & $\begin{array}{c}\text { Storage at beginning } \\
\text { of WY 2017, } \\
\text { in percent }\end{array}$ & $\begin{array}{c}\text { Peak storage } \\
\text { during WY 2017, } \\
\text { in percent }\end{array}$ & $\begin{array}{c}\text { Storage at end } \\
\text { of WY 2017, } \\
\text { in percent }\end{array}$ & $\begin{array}{c}\text { Change in storage, } \\
\text { in percent }\end{array}$ \\
\hline 06857050 & Milford Lake near Junction City, Kansas & 111.6 & 129.8 & 104.3 & -6.5 \\
\hline 06861500 & Cedar Bluff Reservoir near Ellis, Kansas & 32.6 & 33.4 & 30.9 & -5.3 \\
\hline 06865000 & Kanopolis Lake near Kanopolis, Kansas & 127.2 & 186.2 & 108.8 & -14.5 \\
\hline 06868100 & Wilson Lake near Wilson, Kansas & 122.1 & 114.6 & 102.1 & -3.1 \\
\hline 06886900 & Tuttle Creek Lake near Manhattan, Kansas & 105.3 & 208.2 & 115.7 & -5.2 \\
\hline 06890898 & Perry Lake near Perry, Kansas & 140.9 & 164.4 & 112.4 & -20.2 \\
\hline 06891478 & Clinton Lake near Lawrence, Kansas & 111.0 & 130.7 & 109.6 & -1.3 \\
\hline 06910997 & Melvern Lake near Melvern, Kansas & 113.2 & 127.8 & 99.5 & -12.1 \\
\hline 06912490 & Pomona Lake near Quenemo, Kansas & 117.9 & 159.1 & 116.2 & -1.4 \\
\hline 06914995 & Hillsdale Lake near Hillsdale, Kansas & 103.1 & 156.8 & 105.7 & 2.6 \\
\hline 07140885 & Horsethief Reservoir near Jetmore, Kansas & 90.6 & 109.1 & 84.5 & -6.7 \\
\hline 07144790 & Cheney Reservoir near Cheney, Kansas & 103.1 & 124.2 & 95.2 & -7.7 \\
\hline
\end{tabular}


streamflow conditions. This station experienced above average precipitation (fig. 1) and normal to above normal runoff conditions (fig. 5), which kept the 7-day average streamflow at or above normal conditions throughout WY 2017.

Saline River at Tescott, Kans. (station 06869500), represents central Kansas. The Saline River originates in northwestern Kansas and flows east into the Smoky Hill River, near Salina, Kans., and has a drainage area of 2,820 square miles (U.S. Geological Survey, 2017b). Seven-day average flow was much above normal at the beginning of the water year. January, April, May, and June also had several days with much above normal 7-day average streamflow, whereas the remaining months of the WY recorded normal to above normal streamflow (fig. 8). Even though this station received below normal precipitation (fig. 1) and was affected by drought conditions at the end of the WY (fig. 2), the 7-day average streamflow conditions remained normal or above because of regulated outflows from Wilson Lake near Wilson, Kans. (station 06868100; fig. 7; table 1).

Two stations were chosen to represent western Kansas. The first is Crooked Creek near Englewood, Kans. (station 07157500). Crooked Creek originates in southwestern Kansas and flows south

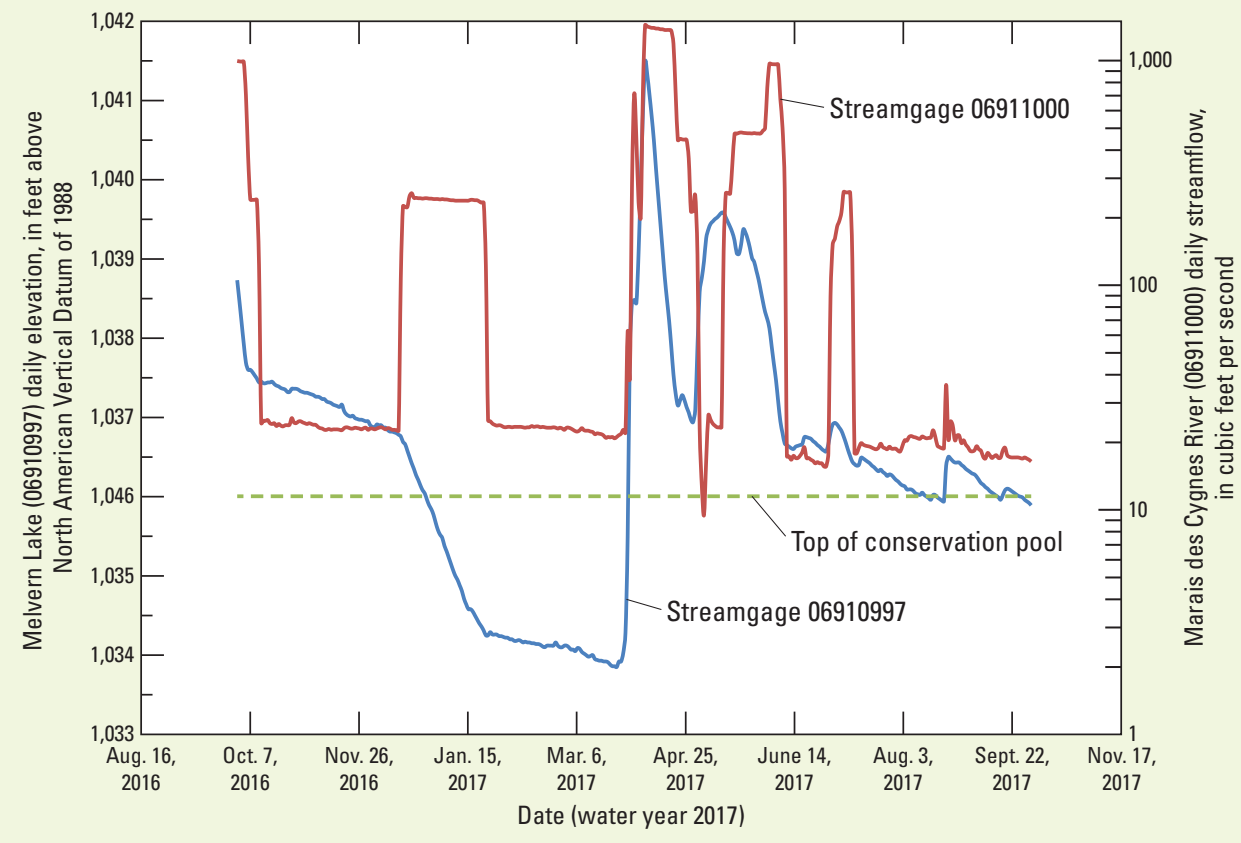

Figure 6. Conservation pool elevation of Melvern Lake near Melvern, Kansas, and daily streamflow of streamgage 06911000 during water year 2017 (U.S. Geological Survey, 2017b).

into the Cimarron River in Oklahoma and has a drainage area of 1,157 square miles (U.S. Geological Survey, 2017b). Sevenday average streamflow was normal at the very beginning of the WY but quickly fell into below normal conditions. Seven-day average streamflow typically was either below normal or much below normal for the first one-half of the WY. The 7-day average streamflow rose to much above normal conditions in April with the heavy spring precipitation received that month. The 7-day average streamflow was normal for most of the second half of

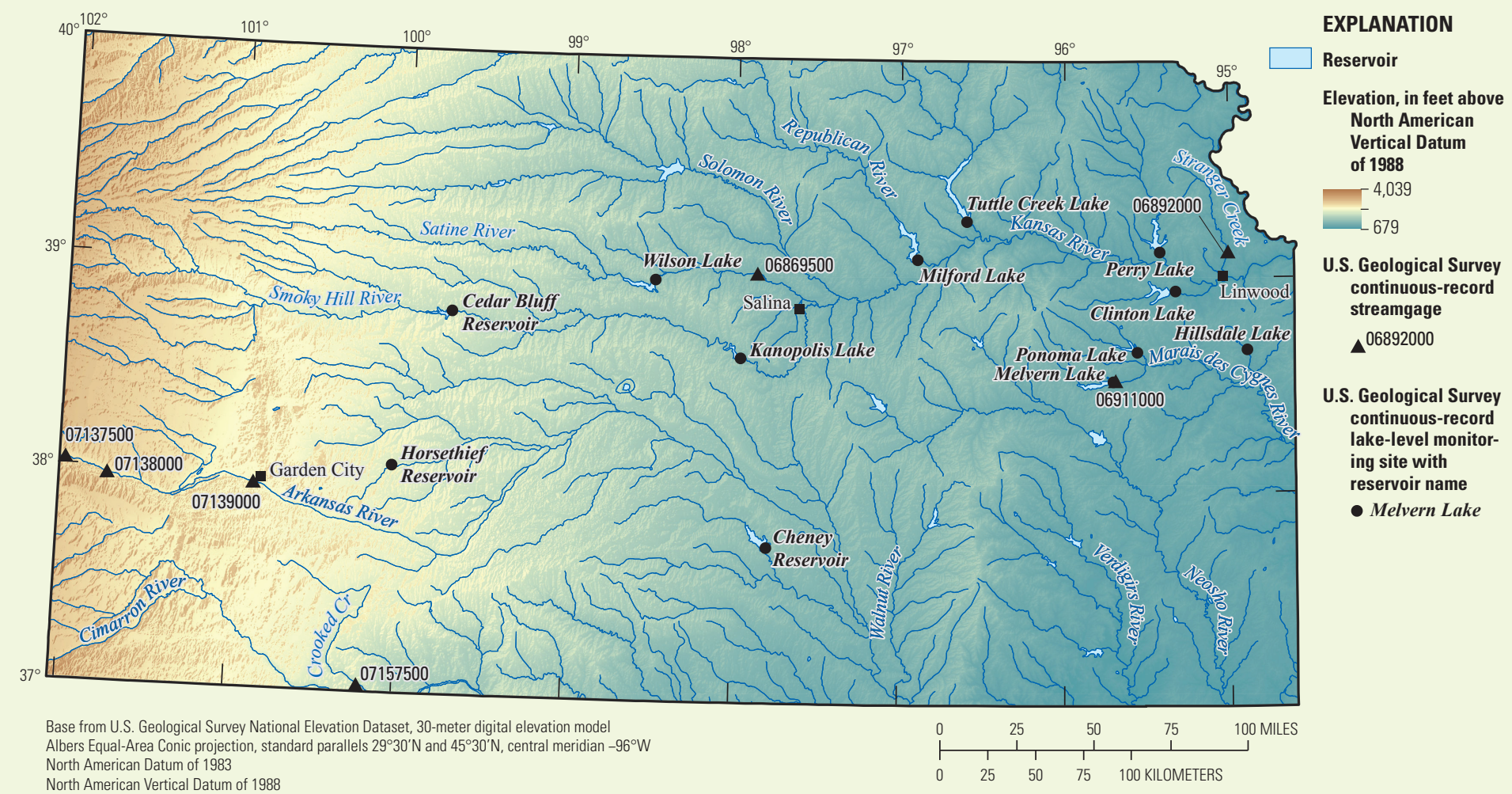

Figure 7. Locations of U.S. Geological Survey monitored reservoirs and selected streamgages. 
WY 2017 (fig. 8). Because of the drought conditions (fig. 2) present at the beginning of WY 2017 the streamflow at this station was below normal or much below normal for the first one-half of the WY.

After having above normal precipitation (fig. 1) during the months of March and April, the streamflow ranged from normal to much above normal for the remainder of the WY.

The second station chosen to represent western Kansas is the Arkansas River at Syracuse, Kans. (station 07138000). The Arkansas River originates in Colorado and flows through Kansas, Oklahoma, and Arkansas into the Mississippi River and has a drainage area of 25,763 square miles at the Syracuse gage (U.S. Geological Survey, 2017b). Flows downstream are regularly diverted for irrigation in western Kansas and for flood control near Wichita, Kans. Like during WY 2016 the 7-day average stream flow was normal for most of the WY. Above normal conditions were present a few times in the spring and summer months (fig. 8). This station received well above normal precipitation (fig. 1) and was minimally affected by drought conditions (fig. 2), helping the streamflow conditions stay normal throughout WY 2017.

\section{Resurgence of the Arkansas River}

The Arkansas River flows into Kansas from Colorado and water is regularly diverted for irrigation in western Kansas. The water is always flowing in the Arkansas River at the gage near Coolidge, Kans. (station 07137500), but in most years the water in the channel of the Arkansas River disappears by Garden City, Kans.; therefore, the cumulative flow at the gage in Garden City, Kans. (station 07139000), can be used to show the downstream extent of flow in the Arkansas River (fig. 7). The cumulative flow for the Arkansas River at Garden City, Kans., gage for WYs 2013-17 is shown in figure 9 . As figure 9 shows, WY 2017 recorded a cumulative flow of about $2,300 \mathrm{ft}^{3} / \mathrm{s}$, which is significantly more flow than the previous 4 WYs (U.S. Geological Survey, 2017a). The annual mean flow for the same gage for WYs 1923-2017 (data not available for WYs 1971-86) is shown in figure 10. Even though the flow recorded at the Arkansas River at Garden City, Kans., gage was the highest seen in the last
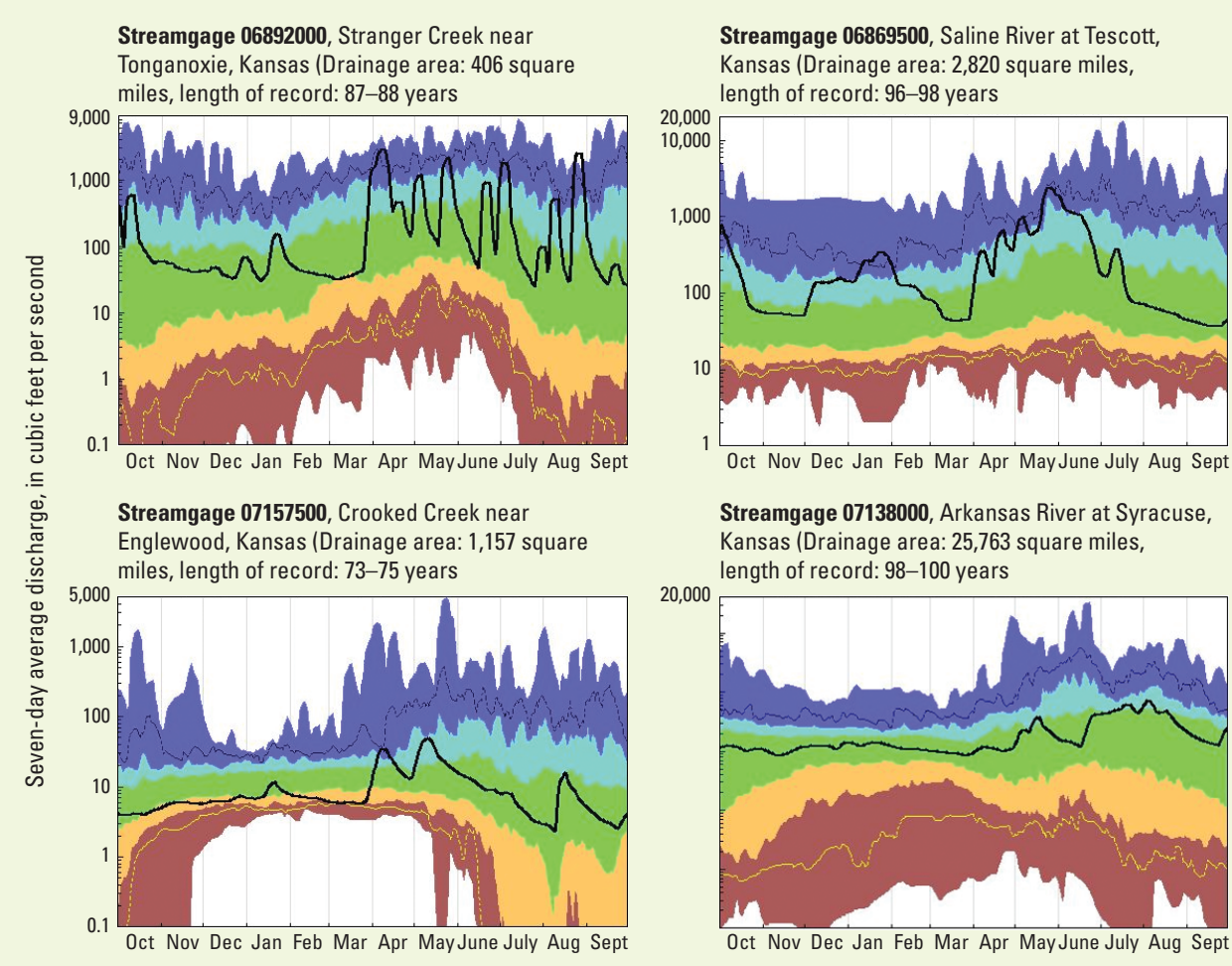

Streamgage 07138000, Arkansas River at Syracuse, Kansas (Drainage area: 25,763 square miles, length of record: $98-100$ years

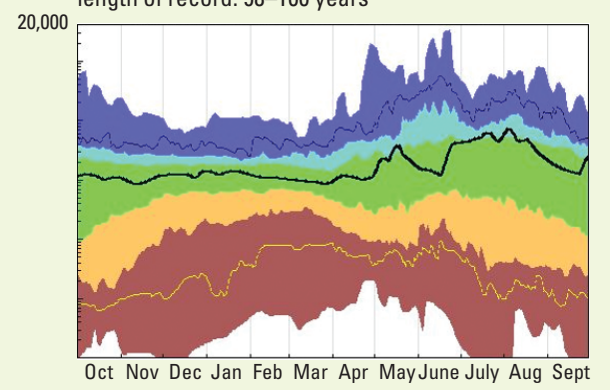

2017

EXPLANATION

\begin{tabular}{|c|c|c|c|c|c|c|c|}
\hline $\begin{array}{c}\text { Lowest- } \\
\text { 10th percentile }\end{array}$ & 5 & $10-24$ & $25-75$ & $76-90$ & 95 & $\begin{array}{c}90 \text { th percentile } \\
\text {-highest }\end{array}$ & Flow \\
\hline Much below normal & $\begin{array}{c}\text { Below } \\
\text { normal }\end{array}$ & Normal & $\begin{array}{c}\text { Above } \\
\text { normal }\end{array}$ & Much above normal & Percentile classes \\
\hline \multicolumn{7}{|c|}{ Clasen }
\end{tabular}

Figure 8. Seven-day average streamflows for water year 2017 for U.S. Geological Survey streamgages $06892000,06869500,07157500$, and 07138000 in Kansas (U.S. Geological Survey, 2017a).

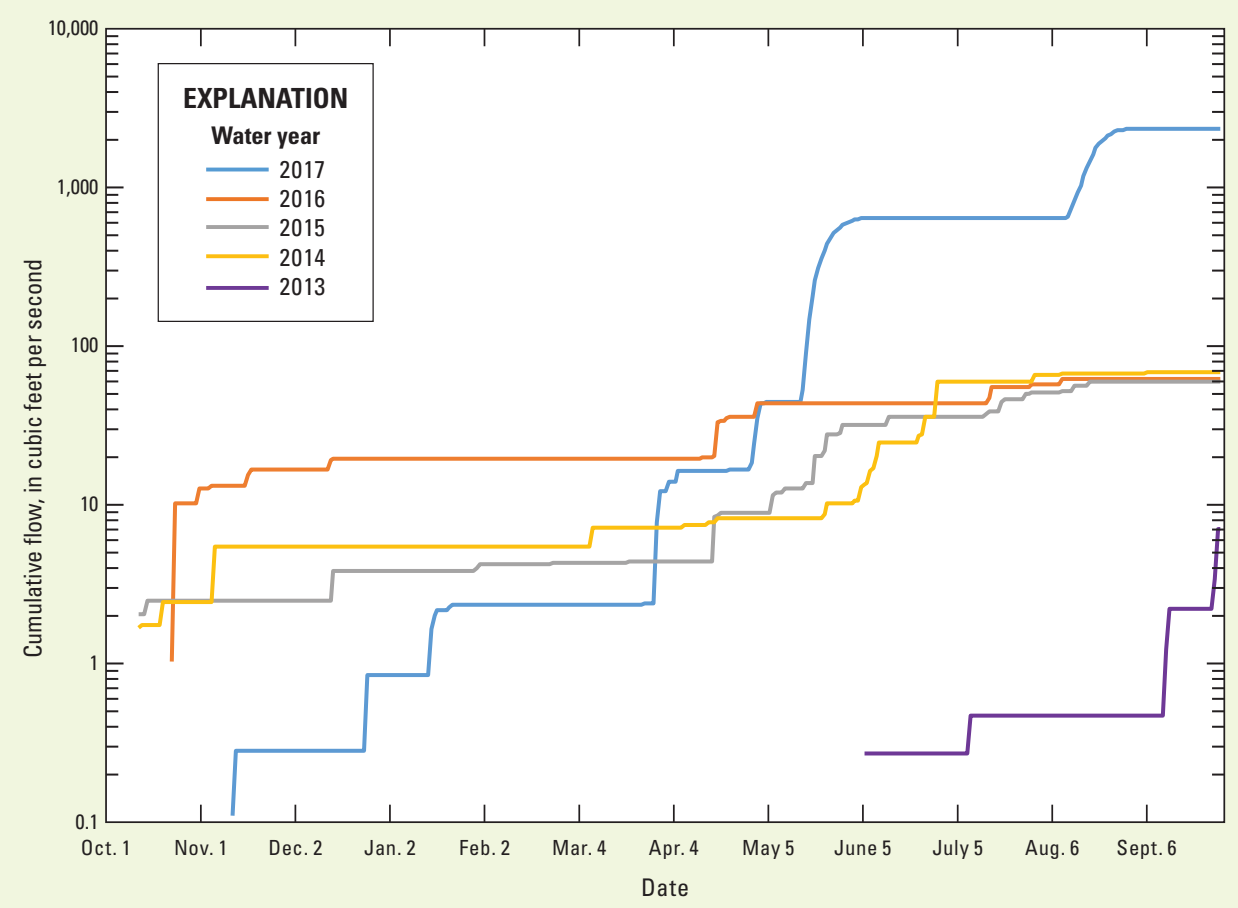

Figure 9. Streamgage 07139000 cumulative streamflow hydrograph for water years 2013-17, Kansas (U.S. Geological Survey, 2017a). 
$5 \mathrm{WYs}$, it is still low when compared to the overall period of record (U.S. Geological Survey, 2017a). The channel at the Garden City gage during a dry period in WY 2013 and a period of flooding in WY 2017 is shown in figure 11. The major factors responsible for streamflow alteration along this reach are local changes to land use and water use as well as groundwater withdrawals (Juracek and others, 2017).

\section{Summary}

Streamflow conditions in Kansas for water year (WY) 2017 were mostly normal. Runoff conditions were mostly normal until the last quarter of WY 2017. The central part of the State received slightly below normal precipitation for the WY, whereas the western and eastern parts received above normal precipitation. The drought conditions worsened from the beginning to the end of the WY. The central and northern areas of the State that ended the WY with below or much below normal streamflow conditions corresponded to the areas effected by drought because of below normal precipitation. However, parts of central and southern Kansas that were affected by the drought conditions finished the WY with normal streamflow conditions because of releases from reservoirs. Eleven of the 12 reservoirs monitored by the U.S. Geological survey finished the WY with less water than at the beginning of the WY. The Arkansas River in southwest Kansas had a greater duration and downstream extent of streamflow during WY 2017 than in recent WYs, as shown by the data recorded at the streamgage in Garden City, Kansas.

\section{References Cited}

Juracek, K.E., Eng, K., Carlisle, D.M., and Wolock, D.M., 2017, Streamflow alteration and habitat ramifications for a threatened fish species in the central United States: River Research and Applications, v. 33, no. 7, p. 993-1003. [Also available at https://doi.org/10.1002/rra.31481002.]

Langbein, W.B., and Iseri, K.T., 1960, General introduction and hydrologic definitions: U.S. Geological Survey Water-Supply Paper 1541-A, 29 p.

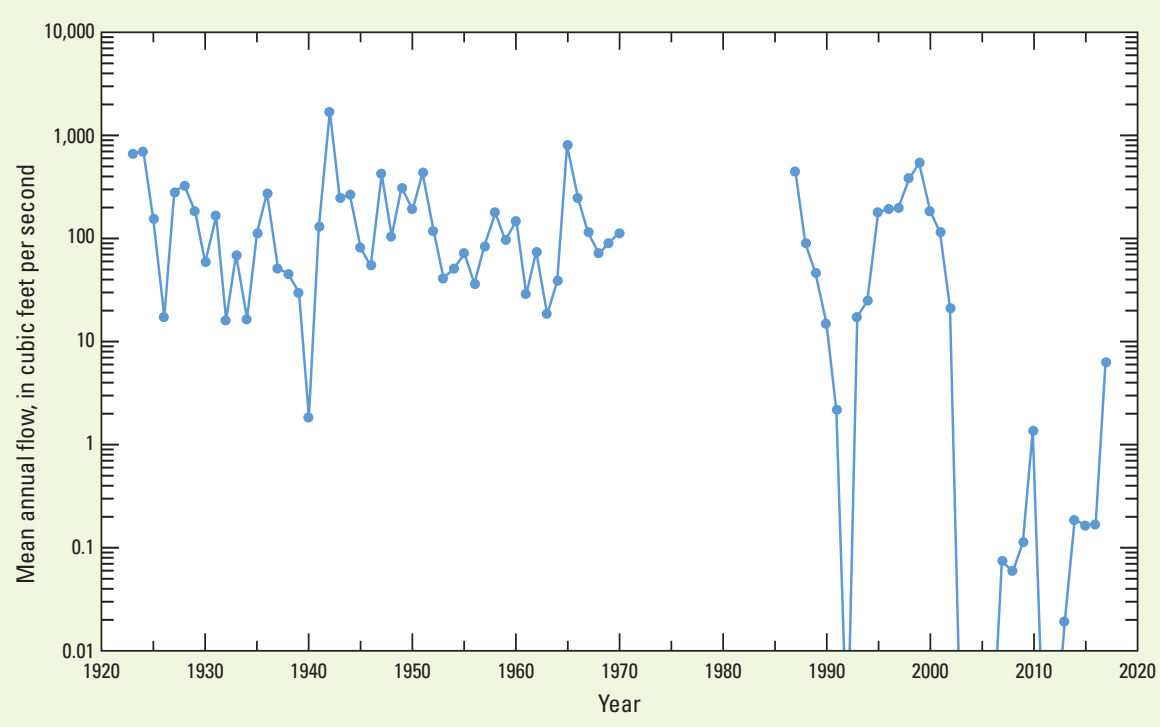

Figure 10. Streamgage 07139000 annual mean flow for water years 1923-70 and 1987-2017, Kansas (U.S. Geological Survey, 2017a).
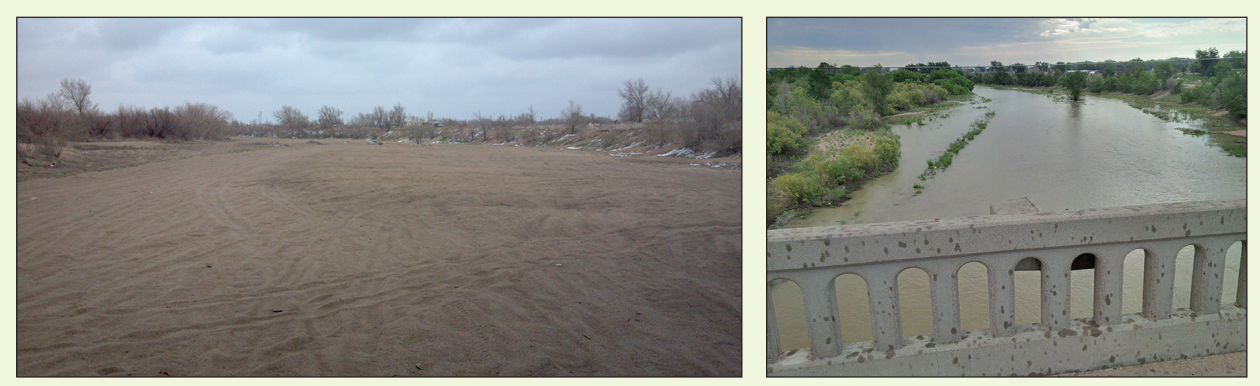

Figure 11. Left, Arkansas River at Garden City, Kansas, in April 2013 (photograph by Andrew Clark, U.S. Geological Survey), and right, in August 2017 (photograph by Lori Marintzer, U.S. Geological Survey).

National Drought Mitigation Center, 2017, U.S. Drought MonitorKansas: National Drought Mitigation Center, U.S. Drought Monitor web page, accessed November 7, 2017, at http://droughtmonitor.unl.edu/.

National Oceanic and Atmospheric Administration, 2017, Advanced hydrologic prediction service-2017 precipitation maps for Kansas: National Oceanic and Atmospheric Administration, National Weather Service, accessed November 7, 2017 , at http://water.weather.gov/precip/.

National Oceanic and Atmospheric Administration, 2018, Climate normals: National Centers for Environmental Information web page, accessed June 29, 2018, at https:/www.ncdc.noaa.gov/dataaccess/land-based-station-data/landbased-datasets/climate-normals.
U.S. Geological Survey, 2017a, WaterWatch-Current water resources in Kansas: U.S. Geological Survey website, accessed November 7, 2016, at https://waterwatch.usgs.gov/.

U.S. Geological Survey, 2017b, USGS water data for the Nation: U.S. Geological Survey National Water Information System database, accessed November 7, 2017, at https://doi.org/10.5066/F7P55KJN.

\section{For additional information con- cerning this publication, contact:}

Director, USGS Kansas Water

Science Center

1217 Biltmore Dr.

Lawrence, KS 66049

(785) 842-9909

Or visit the Kansas Water

Science Center website at:

https://ks.water.usgs.gov 